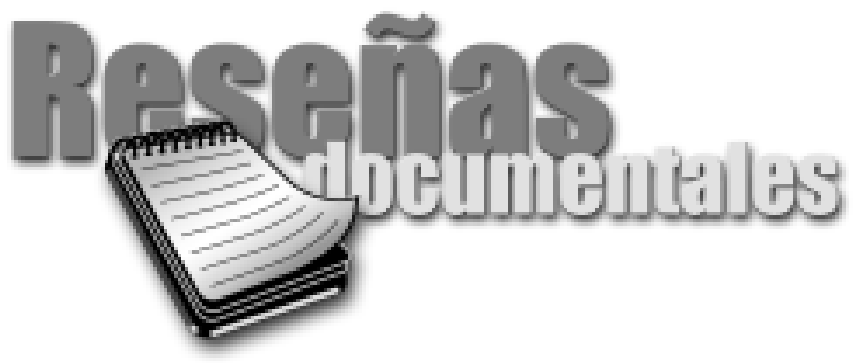

\section{Veinte poemas de amor y una canción desesperada}

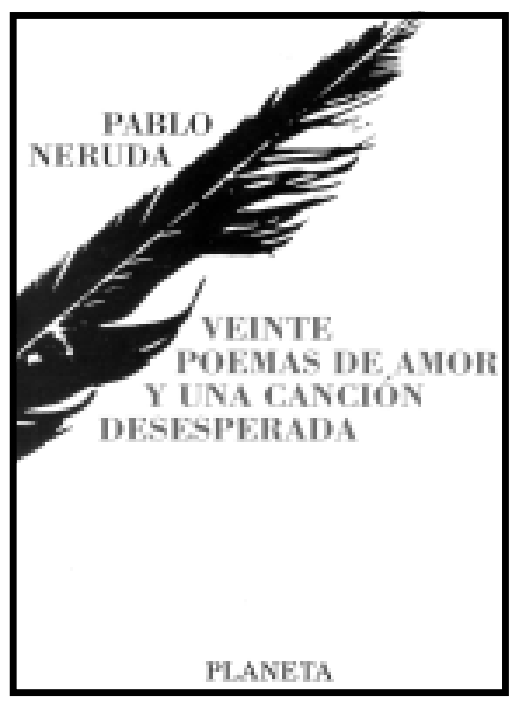

Publicado por primera vez en 1924, Veinte poemas de amor y una canción desesperada es quizá el libro de Neruda que ha obtenido una más vasta popularidad entre el público común y a la vez significó la plena consolidación del prestigio literario de su autor en el área hispánica. Tan legítima es aquí la popularidad de la obra como la consideración de su estatura literaria: el remanente de la herencia modernista a los hallazgos expresivos de la nueva vanguardia en una serie de piezas de conmovida intensidad lírica, cuyo acento de plenitud vital, exaltación genésica y erotismo panteísta cede el paso, en la hora de los duelos y las separaciones, a un tono de melancolía que le hermana a la herencia romántica. Intocables en su definitiva rotundidad de pieza maestra, estos Veinte poemas de amor y una canción desesperada constituyen; sin duda, una de las mayores cimas de la poesía amorosa en la lengua castellana.

\section{FiCHA TÉENICA}

Titulo: Veinte poemas de amor y una canción desesperada

Autor: Pablo Neruda.

Editorial Planeta Chilena

Lugar y fecha de publicación:

Publicado por primera vez en 1924

Autor de la reseña: Nelson Pineda 